\title{
Systemic Treatment of Psoriasis with JAK Inhibitors: A Review
}

\author{
Amanda Kvist-Hansen · Peter Riis Hansen · Lone Skov
}

Received: November 7, 2019 / Published online: December 31, 2019

(c) The Author(s) 2019

\begin{abstract}
Psoriasis is a prevalent chronic inflammatory disease. The inflammatory response is driven by $\mathrm{T}$ cells and mediated by multiple cytokines such as tumor necrosis factor and the interleukins IL17 and IL-23. Moderate-to-severe psoriasis is treated systemically, using either biologics or conventional treatments with small-molecule drugs. The newer biologics are very effective and well tolerated, but not all patients respond
\end{abstract}

Enhanced Digital Features To view enhanced digital features for this article go to https://doi.org/10.6084/ m9.figshare.11316773.

A. Kvist-Hansen $(\bowtie)$

Department of Dermatology and Allergy, Herlev and Gentofte Hospital, University of Copenhagen, Copenhagen, Denmark

e-mail: amanda.kvist-hansen@regionh.dk

P. R. Hansen

Department of Cardiology, Herlev and Gentofte Hospital, University of Copenhagen, Copenhagen, Denmark

\section{Skov}

Department of Dermatology and Allergy, Herlev and Gentofte Hospital, University of Copenhagen,

Copenhagen, Denmark to treatment with biologics, so there is a need for new treatment options for psoriasis. Janus kinase (JAK) inhibitors are a new drug class that may be of use in this respect. These inhibitors are already on the market for rheumatoid arthritis, psoriatic arthritis, and ulcerative colitis. They block the intracellular signal pathway mediated by JAK and signal transducer and activator of transcription (STAT) proteins, thereby inhibiting gene transcription of proinflammatory cytokines. JAK inhibitors are currently being tested as potential treatments for psoriasis. They have shown clinical efficacy as measured by the Psoriasis Area and Severity Index 75 response in both phase 2 and 3 trials, and appear to be well tolerated overall. This review provides an overview of the mechanisms underlying the actions of JAK inhibitors in psoriasis, together with the results of clinical trials testing their efficacies when used to treat the disease.

Keywords: Efficacy; JAK inhibitors; JAK-STAT signaling pathway; Psoriasis; Tofacitinib; Treatment; TYK2 inhibitors 


\section{Key Summary Points}

Psoriasis is a prevalent chronic inflammatory disease. The inflammatory response is driven by $\mathrm{T}$ cells and mediated by multiple cytokines such as tumor necrosis factor (TNF) and the interleukins IL-17 and IL-23.

Janus kinase (JAK) inhibitors are a potential new systemic treatment option for psoriasis.

JAK inhibitors block the production of proinflammatory cytokines in psoriasis by inhibiting the JAK-signal transducer and activator of transcription (STAT) signaling pathway downstream of the receptor.

Different JAK inhibitors have been and are currently being tested in phase 2 and 3 clinical trials as treatments for moderateto-severe psoriasis.

The results of these trials have demonstrated the clinical efficacy of JAK inhibitors in psoriasis as measured by PASI75, and have shown that they have a safety profile comparable to biologics already on the market. However, these results are based on short-term use, and more studies are needed to determine the long-term efficacy and safety of JAK inhibitors in psoriasis.

\section{INTRODUCTION}

Psoriasis is a systemic chronic inflammatory disease characterized by scaly erythematous lesions of the skin. The skin of psoriatic lesions typically shows epidermal hyperplasia and parakeratosis together with an accumulation of inflammatory cells in the dermis. The inflammatory response is driven by $\mathrm{T}$ cells, especially $\mathrm{T}$ helper (Th) 17 cells, and is mediated by multiple cytokines, especially tumor necrosis factor (TNF), interleukin (IL)-17 and IL-23 [1, 2].
Psoriasis can be classified into mild, moderate, or severe disease according to the Psoriasis Area and Severity Index (PASI). Mild disease can often be controlled by topical treatment, whereas moderate-to-severe disease additionally requires systemic treatment or phototherapy [2]. Systemic treatments can be divided into treatments utilizing small-molecule drugs and monoclonal antibodies (biologics). Treatment with biologics is very effective in psoriasis and is well tolerated overall. New biologics are much more effective than conventional treatments with small-molecule drugs $[1,3]$, but they do have limitations. Some patients with psoriasis do not respond to the treatment, while other patients experience a loss of drug response during treatment. Overall, drug survival of older biologics is $70-80 \%$ after 1 year of treatment $[4,5]$. The side effects of biologics are relatively limited, but these drugs must be administered by subcutaneous injection, and they are expensive. Therefore, new treatment options for psoriasis are needed. One possibility is a new class of small-molecule drugs called Janus kinase (JAK) inhibitors, which are currently being tested in clinical trials.

\section{JAKS AND THEIR SIGNALING PATHWAY}

The JAKs are four intracellular protein tyrosine kinases: JAK1, JAK2, JAK3, and tyrosine kinase 2 (TYK2) [6]. JAK1, JAK2, and TYK2 are expressed in a variety of cell types, while JAK3 is mainly expressed in hematopoietic cells [7]. JAK inhibitors are small-molecule drugs that inhibit JAKs and thereby hinder the function of the JAK-signal transducer and activator of transcription (STAT) signal pathway. In contrast to biologics that target either the extracellular cytokine receptor or the cytokine outside the cell, JAK inhibitors target JAKs inside the cell that contribute to signal transduction.

The term "cytokine" covers many structurally unrelated proteins. They can be grouped based on the receptor superfamily they bind to. Different receptor superfamilies use different kinds of signal transduction pathways. Many proinflammatory cytokines-for example IL-23, 


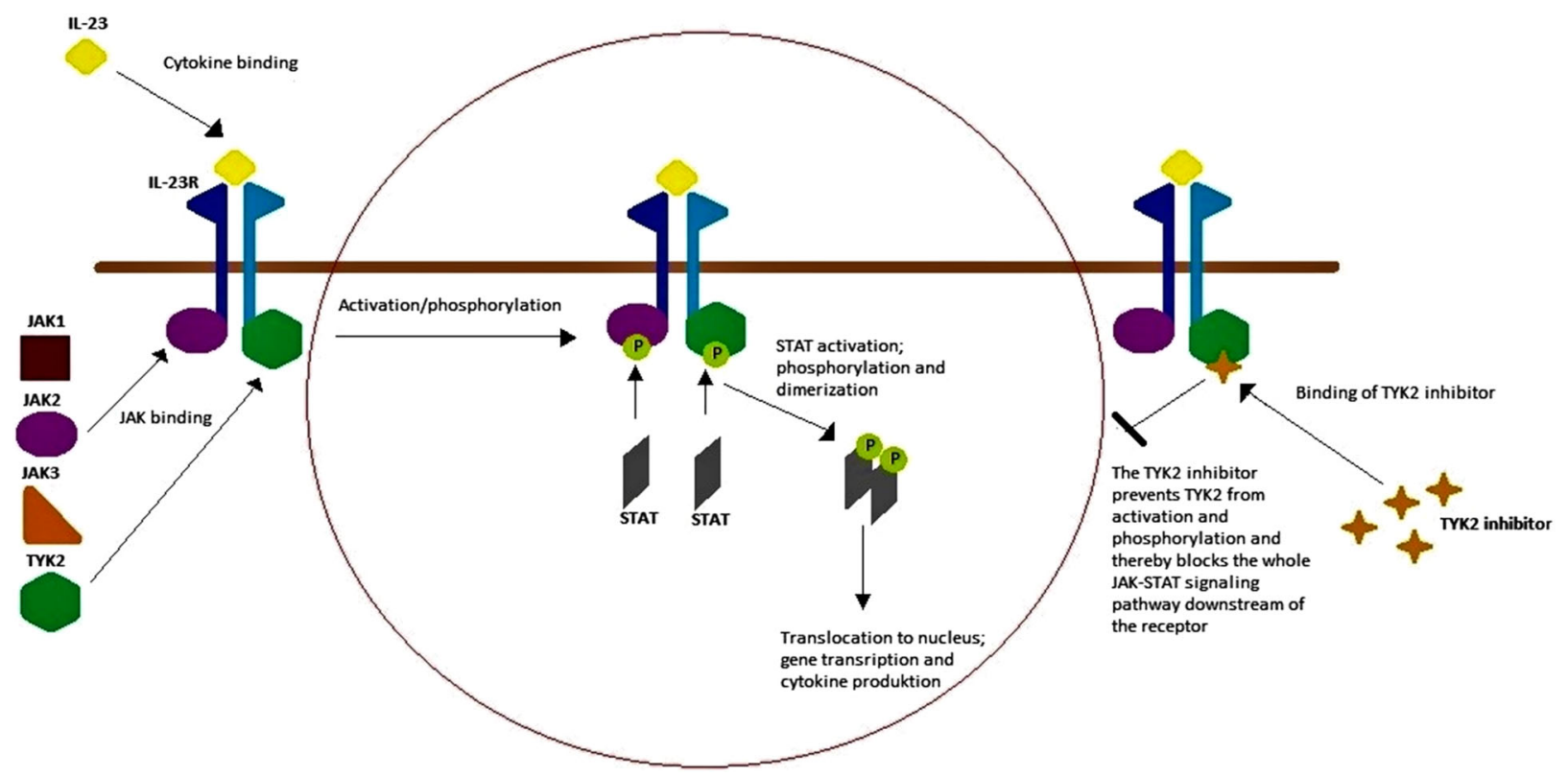

Fig. 1 Overview of the interleukin (IL)-23 signal pathway and the mechanism of tyrosine kinase (TYK) 2 inhibition. The IL-23 signal pathway is implicated in the pathogenesis of psoriasis and is an example of a signal pathway that is mediated by Janus kinases (JAKS) and signal transducer and activator of transcription (STAT) proteins. There are four JAKs: JAK1, JAK2, JAK3, and TYK2. When IL-23 binds to the IL-23 receptor $(R)$, it attracts a heterodimer of JAK2 and TYK2 that binds to the intracellular domain of the receptor. JAK2 and TYK2 then autophosphorylate

which is part of the inflammatory response in psoriasis-bind to type I and II cytokine receptors, which leads to the activation of intracellular signaling mediated by JAKs [6]. When a cytokine binds to a receptor on the cell surface, intracellular JAKs are recruited and bind in pairs to the intracellular part of the receptor. The dimerization of JAKs, in most cases with formation of heterodimers, causes autophosphorylation and modifies the receptors so that STAT proteins can bind and become activated. Activated STAT proteins then dimerize and translocate to the cell nucleus to regulate gene transcription [8]. In psoriasis, inhibition of JAKs results in inhibition of the signal pathway and gene transcription, leading to further production of inflammatory cytokines, thereby reducing psoriatic inflammation (Fig. 1).
$(P)$, which activates the receptor and attracts STAT proteins. The STAT proteins bind and are phosphorylated before dimerizing and translocating to the cell nucleus, where they regulate gene transcription and thus further cytokine production. TYK2 inhibitors inhibit TYK2 function, which in turn suppresses intracellular signal transduction downstream of the receptor and thus further cytokine production through IL-23 during the psoriatic inflammation process

The functions of each JAK and of JAKs in general are not yet fully understood. JAK1 is associated with interferon (IFN) and IL- 6 and IL10 receptors and with receptors containing the common $\gamma$ chain or the gp130 subunit. JAK2 is associated with the IL-3 receptor and hormonelike receptors, e.g., those for erythropoietin, growth hormone, and prolactin; these receptors are dependent on a homodimer of JAK2 for intracellular signal transduction. Dimers of JAK2 and TYK2 are associated with INF, IL-12, and IL-23 receptors. JAK3 is limited to hematopoietic cells and binds in conjunction with JAK1 exclusively to receptors containing $\gamma$ chains, which include IL-2, IL-4, IL-7, IL-9, IL15 , and IL-21 receptors. JAK dysfunction is associated with polycythemia vera, essential thrombocytopenia, myelofibrosis, and severe combined immunodeficiency and 
hyperimmunoglobulin E syndrome. Furthermore, dysregulation of JAK signaling is seen in various autoimmune diseases $[8,9]$.

\section{JAK INHIBITORS IN PSORIASIS}

The IL-23/Th17 axis is key part of the pathogenesis of psoriasis. IL-23 drives the differentiation of Th17 cells. These cells produce IL-17 and IL-22, which induce keratinocyte proliferation and other features typical of psoriasis [2]. Several biologics used for psoriasis, such as ustekinumab, secukinumab, ixekizumab, guselkumab, risankizumab, tildrakizumab, and brodalumab, target this axis. The IL-23 receptor relies on a heterodimer of JAK2 and TYK2 for signal transduction, thus highlighting the role of JAKs in the pathogenesis of psoriasis and the therapeutical potential of JAK inhibitors [10]. Furthermore, TYK2-deficient mice display significantly reduced ear swelling and less epidermal hyperplasia when injected with IL-23 compared to wild-type mice. Skin infiltration of various immune cells and production of the proinflammatory cytokines IL-17 and IL-22 were also impaired in the absence of TYK2 [11]. These results, together with the known clinical success of biologics targeting the IL23/IL17 axis, shows the great potential for JAK inhibitors and perhaps particularly for TYK2 inhibitors in the treatment of psoriasis.

The JAK inhibitors currently tested in clinical trials target different members of the JAK family, with some being more selective than others. First-generation JAK inhibitors typically target two or three different JAKs and thus have a broader effect but also present more side effects compared to the newer generation (e.g., selective TYK2 inhibitors), which specifically target one JAK [6]. To date, three JAK inhibitors have been approved and are on the market for the treatment of various human diseases: ruxolitinib for myelofibrosis and polycythemia vera, tofacitinib for rheumatoid arthritis (RA), psoriatic arthritis, and ulcerative colitis, and baricitinib for RA [6].

The aim of the present review is to provide an overview of the mechanism underlying the effects of JAK inhibitors on psoriasis as well as the results of clinical trials testing their efficacy in treating this disease.

\section{METHODS}

Our search included literature published in English on clinical trials of JAK inhibitors in adults with chronic plaque psoriasis. We searched the Medline database via PubMed until 1 August 2019 using the following combinations of MeSH search terms: "psoriasis" AND "janus kinases;" "psoriasis" AND "TYK2 kinase;" and "psoriasis" AND "tofacitinib." Further trials were searched for manually in the reference lists of relevant papers. We additionally searched clinicaltrials.gov for unpublished trials. We only included clinical phase 2 or 3 trials examining the efficacy and safety of systemic JAK and TYK2 inhibitors compared to placebo, another active treatment, or no treatment in adult patients with chronic plaque psoriasis. This article is based on previously conducted studies and does not contain any studies with human participants or animals performed by any of the authors.

\section{RESULTS}

\section{Tofacitinib and Psoriasis}

Tofacitinib is the most studied JAK inhibitor for treatment of chronic plaque psoriasis. Tofacitinib primarily targets JAK3, JAK2, and JAK1. It is a first-generation JAK inhibitor that is on the market as a treatment for RA, psoriatic arthritis, and ulcerative colitis $[7,9]$. We identified five clinical trials testing tofacitinib in psoriasis, including one phase 2 trial and four phase 3 trials (Table 1). All studies were performed in patients with moderate-to-severe plaque psoriasis, classified as PASI $>12$ (phase 3 studies) or PASI $>13$ (phase 2 study). In the phase 2 study, tofacitinib had efficacies of $25.0 \%$ ( $2 \mathrm{mg}$ twice daily), $40.8 \%$ (5 $\mathrm{mg}$ twice daily), and $66.7 \%$ (15 mg twice daily) compared to $2 \%$ for the placebo in terms of PASI75 response at week 12 of treatment [12]. Across the phase 3 studies, tofacitinib had efficacies of $39.5-54.3 \%$ (5 mg 


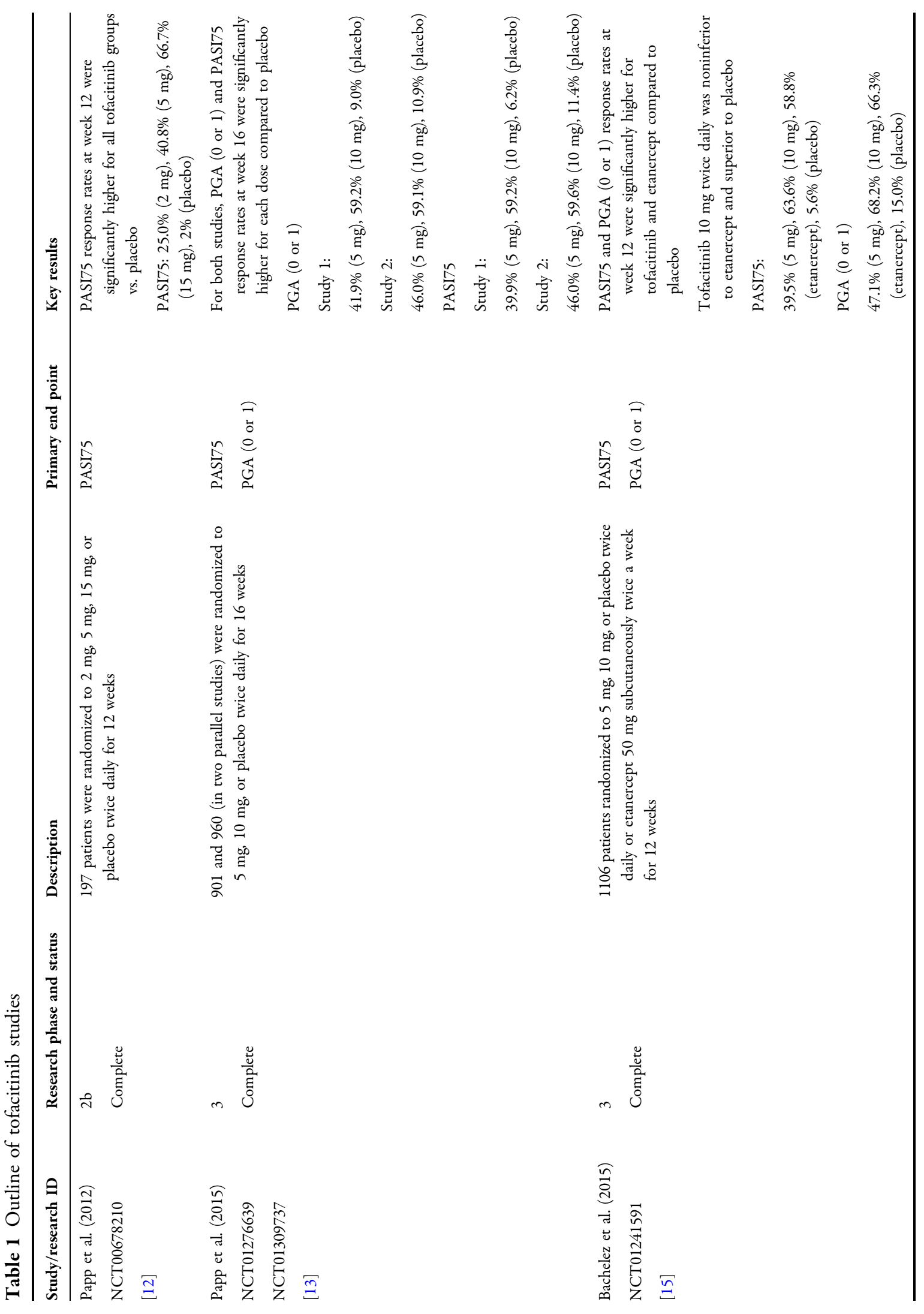




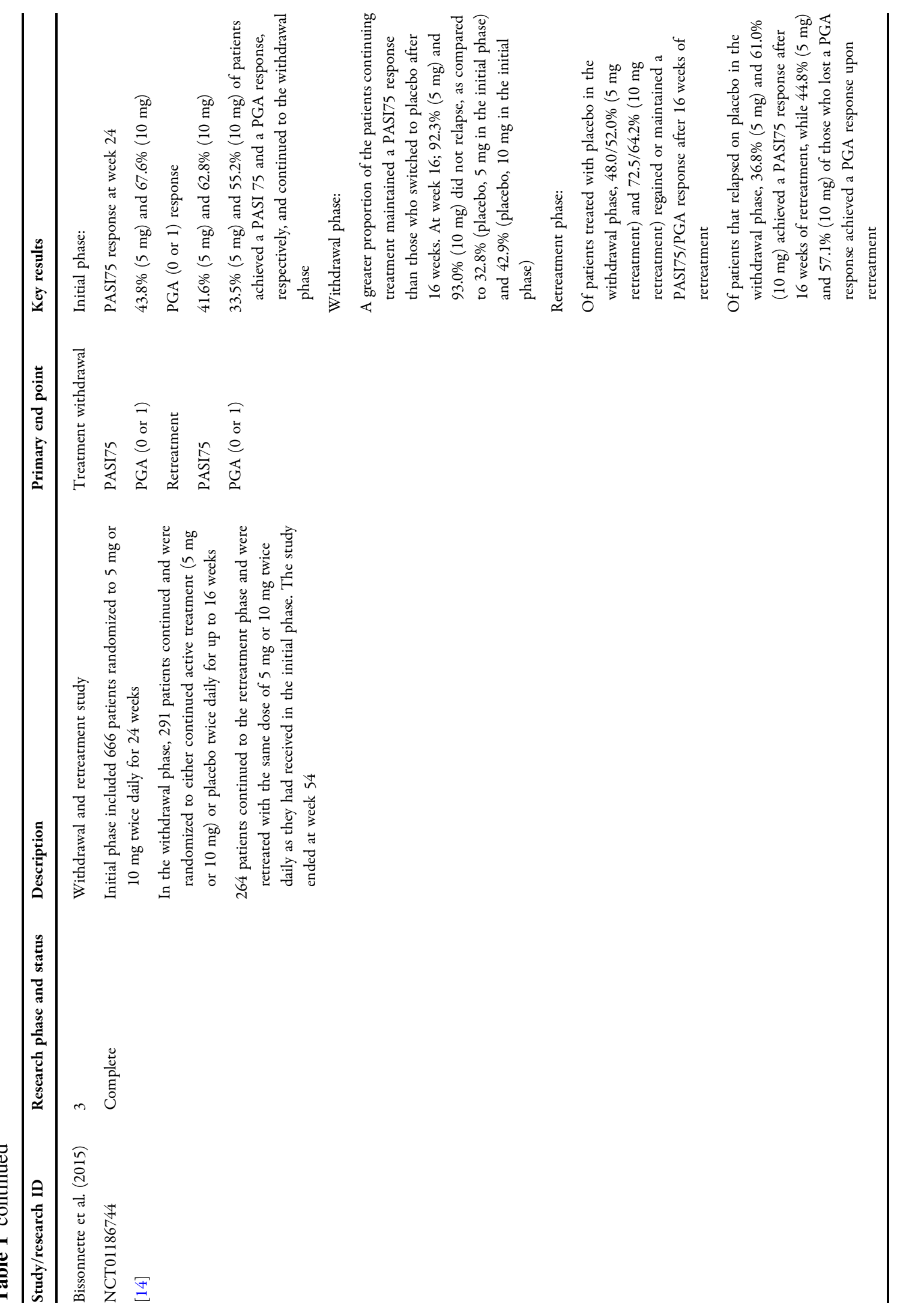




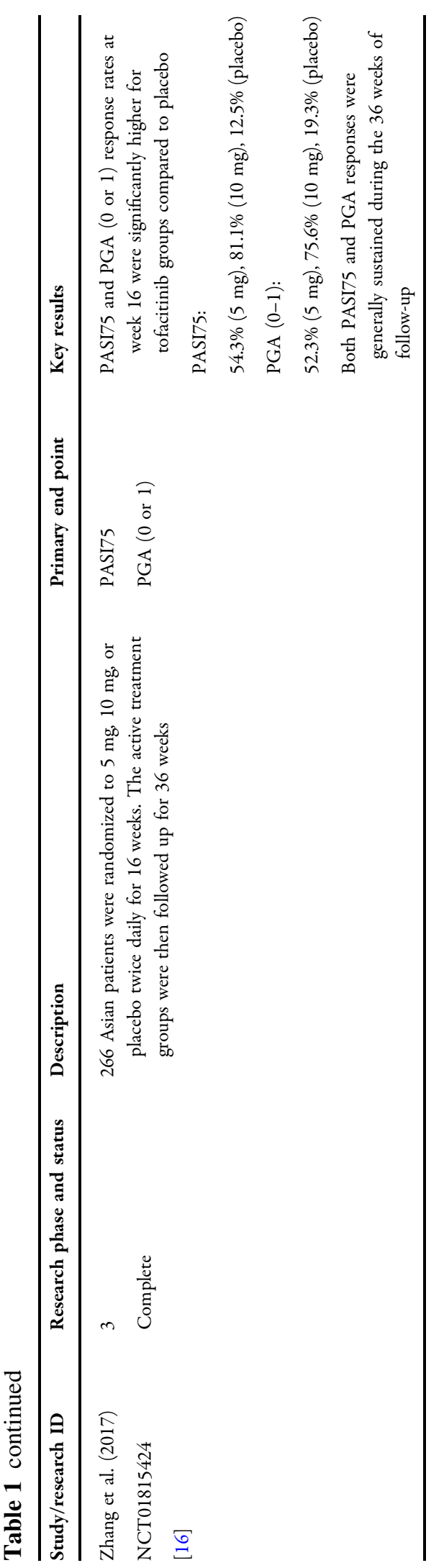

twice daily) and 59.2-81.1\% (10 mg twice daily) compared to $5.6-12.5 \%$ for the placebo in terms of PAS75 response at weeks 16-24 [13-16]. The highest PASI75 responses at both dosages were observed in an Asian population [16]. These studies also showed the clinical efficacy of tofacitinib for secondary end points such as the Dermatology Life Quality Index (DLQI), Nail Psoriasis Severity Index (NAPSI), and PASI90 compared to placebo. None of the tofacitinib studies included PASI100 responses. In one study, treatment with tofacitinib was noninferior to treatment with etanercept [15]. While tofacitinib was well tolerated overall, the following were observed in most studies: increased circulating total cholesterol, low-density lipoprotein (LDL) cholesterol, high-density lipoprotein (HDL) cholesterol, and creatinine phosphokinase levels and decreased blood hemoglobin and lymphocyte counts.

\section{TYK2 Inhibitors and Psoriasis}

TYK2 inhibitors were developed to obtain more selective inhibitors than first-generation JAK inhibitors. The TYK2 inhibitor BMS-986165 has been tested in one phase 2 trial, where the PASI75 response was $75 \%$ compared to $7 \%$ in the placebo group after 12 weeks of treatment with the highest dosage tested (12 mg daily). Secondary end points included PASI90 and PASI100 responses. The PASI90 response was $43 \%$ after 12 weeks (daily dose of $12 \mathrm{mg}$ ) compared to placebo. The PASI100 response was $25 \%$ after 12 weeks (daily dose of $12 \mathrm{mg}$ ) compared to placebo. The treatment did not lead to significant changes in blood cell counts or serum levels of liver enzymes, lipids, creatinine, and immunoglobulins [17]. However, there were three serious adverse events in the BMS986165 groups, as well as one case of malignant melanoma that occurred 3 months after the start of treatment. According to clinicaltrials.gov, three phase 3 trials testing BMS-986165 are in progress. Another TYK2 inhibitor (PF06826647) is also currently being tested in a phase 2 study (Table 2). However, TYK2 inhibitors are yet to enter the market. 
Table 2 Outline of TYK2 inhibitor studies

\begin{tabular}{|c|c|c|c|}
\hline $\begin{array}{l}\text { Study/drug/ } \\
\text { research ID }\end{array}$ & $\begin{array}{l}\text { Research } \\
\text { phase and } \\
\text { status }\end{array}$ & Description & Key results \\
\hline $\begin{array}{l}\text { Papp et al. } \\
\quad(2018) \text { BMS- } \\
986165 \\
\text { NCT02931838 } \\
\text { [17] }\end{array}$ & $\begin{array}{l}2 \\
\text { Complete }\end{array}$ & $\begin{array}{l}267 \text { patients randomized to } 3 \mathrm{mg} \text { every } \\
\text { other day, } 3 \mathrm{mg} \text { daily, } 3 \mathrm{mg} \text { twice daily, } \\
6 \mathrm{mg} \text { twice daily, } 12 \mathrm{mg} \text { daily, or placebo } \\
\text { for } 12 \text { weeks }\end{array}$ & $\begin{array}{l}\text { All groups receiving the study drug (except } \\
\text { the } 3 \mathrm{mg} \text { every other day group) had a } \\
\text { significantly greater PASI } 75 \text { response at } \\
\text { week } 12 \text { compared to placebo } \\
\text { PASI75: } 9 \% \text { ( } 3 \mathrm{mg} \text { every other day), } 39 \% \\
\text { ( } 3 \mathrm{mg} \text { daily) } 69 \% \text { ( } 3 \mathrm{mg} \text { twice daily), } 67 \% \\
\text { (6 mg twice daily), } 75 \% \text { (12 mg daily), } 7 \% \\
\text { (placebo) }\end{array}$ \\
\hline $\begin{array}{l}\text { BMS-986165 } \\
\text { NCT04036435 } \\
{[41]}\end{array}$ & $\begin{array}{l}3 \\
\text { Not } \\
\text { recruiting } \\
\text { yet }\end{array}$ & Safety and efficacy study & - \\
\hline $\begin{array}{l}\text { BMS-986165 } \\
\text { NCT03924427 } \\
{[42]}\end{array}$ & $\begin{array}{l}3 \\
\text { Recruiting }\end{array}$ & $\begin{array}{l}\text { Safety and efficacy evaluation in Japanese } \\
\text { patients }\end{array}$ & - \\
\hline $\begin{array}{l}\text { BMS-986165 } \\
\text { NCT03611751 } \\
\text { NCT03624127 } \\
{[43,44]}\end{array}$ & $\begin{array}{l}3 \\
\text { Recruiting }\end{array}$ & $\begin{array}{l}\text { Two parallel studies of efficacy compared to } \\
\text { apremilast and placebo }\end{array}$ & - \\
\hline $\begin{array}{l}\text { PF06826647 } \\
\text { NCT03895372 } \\
{[45]}\end{array}$ & $\begin{array}{l}2 \\
\text { Recruiting }\end{array}$ & Safety and efficacy study & - \\
\hline
\end{tabular}

\section{Other JAK Inhibitors and Psoriasis}

Four other JAK inhibitors have been tested as treatments for psoriasis: peficitinib (ASP015K), a pan-JAK inhibitor; solcitinib (GSK 2586184), a JAK1 inhibitor; baricitinib, an inhibitor of JAK1 and JAK2; and itacitinib adipate, a JAK1 inhibitor (Table 3) [18-21]. The efficacies of these JAK inhibitors were either similar or inferior to that of tofacitinib. No serious adverse events were reported for peficitinib, baricitinib, and itacitinib, but changes in laboratory parameters similar to those reported for tofacitinib were observed in most studies [19-21]. For solcitinib, five serious adverse events were reported, two of which were considered to be related to the study treatment, including one case of ureteral calculus and one case of severe thrombocytopenia. No changes in other laboratory parameters were reported [18]. All of these studies were phase 2 studies, and no further studies of these JAK inhibitors in relation to the treatment of psoriasis are planned to our knowledge. 
Table 3 Outline of other JAK inhibitor studies

\begin{tabular}{|c|c|c|c|c|}
\hline $\begin{array}{l}\text { Study/drug/ } \\
\text { research ID }\end{array}$ & $\begin{array}{l}\text { Research } \\
\text { phase } \\
\text { and } \\
\text { status }\end{array}$ & Description & $\begin{array}{l}\text { Primary } \\
\text { end point }\end{array}$ & Key results \\
\hline $\begin{array}{l}\text { Papp et al. } \\
\qquad(2015) \\
\text { ASP015K } \\
\text { NCT01096862 } \\
{[20]}\end{array}$ & Complete & $\begin{array}{l}124 \text { patients were randomized to } \\
10 \mathrm{mg} \text { twice daily, } 25 \mathrm{mg} \text { twice } \\
\text { daily, } 60 \mathrm{mg} \text { twice daily, } 100 \mathrm{mg} \\
\text { twice daily, } 50 \mathrm{mg} \text { once daily, or } \\
\text { placebo for } 6 \text { weeks }\end{array}$ & $\begin{array}{l}\text { Mean PASI } \\
\text { reduction } \\
\text { from } \\
\text { baseline }\end{array}$ & $\begin{array}{l}\text { All treatment groups showed } \\
\text { significant improvements in PASI } \\
\text { compared to placebo } \\
\text { Dose-dependent effect observed } \\
\text { Mean change in PASI from baseline: } \\
-6.4 \text { ( } 10 \mathrm{mg} \text { twice daily), }-6.5 \\
\text { ( } 25 \mathrm{mg} \text { twice daily), }-8.3 \text { (60 mg } \\
\text { twice daily), }-11.9 \text { (100 mg twice } \\
\text { daily), }-6.6 \text { ( } 50 \mathrm{mg} \text { once daily), - } \\
4.2 \text { (placebo) }\end{array}$ \\
\hline $\begin{array}{l}\text { Ludbrook et al. } \\
\qquad(2016) \\
\text { GSK2586184 } \\
\text { NCT01782664 } \\
{[18]}\end{array}$ & $\begin{array}{l}2 \mathrm{a} \\
\text { Complete }\end{array}$ & $\begin{array}{l}60 \text { patients were randomized to } \\
100 \mathrm{mg}, 200 \mathrm{mg}, 400 \mathrm{mg} \text {, or } \\
\text { placebo twice daily for } 12 \text { weeks }\end{array}$ & PASI75 & $\begin{array}{l}\text { PASI } 75 \text { response rate at week } 12 \text { for } \\
\text { the } 400 \mathrm{mg} \text { group was significantly } \\
\text { different from that of the placebo } \\
\text { group. Dose-dependent } \\
\text { improvements in PASI } 75 \\
\text { described: } 13 \%(100 \mathrm{mg}), 25 \% \\
\text { (200 mg), } 57 \%(400 \mathrm{mg}), 0 \% \\
\text { (placebo) }\end{array}$ \\
\hline $\begin{array}{l}\text { Papp et al. } \\
\qquad(2016) \\
\text { Baricitinib } \\
\text { NCT01490632 } \\
{[21]}\end{array}$ & $\begin{array}{l}2 \mathrm{~b} \\
\text { Complete }\end{array}$ & $\begin{array}{l}238 \text { North American patients were } \\
\text { randomized to } 2 \mathrm{mg}, 4 \mathrm{mg}, 8 \mathrm{mg} \text {, } \\
10 \mathrm{mg} \text { once daily, or placebo for } \\
12 \text { weeks }\end{array}$ & PASI75 & $\begin{array}{l}\text { PASI75 response at week } 12 \text { was only } \\
\text { significantly different for the } 8 \mathrm{mg} \\
\text { group ( } 43 \% \text { ) and the } 10 \mathrm{mg} \text { group } \\
(54 \%) \text { compared to placebo }(17 \%)\end{array}$ \\
\hline $\begin{array}{l}\text { Bissonnette } \\
\text { et al. (2016) } \\
\text { INCB039110 } \\
\text { NCT01634087 } \\
{[19]}\end{array}$ & $\begin{array}{l}2 \\
\text { Complete }\end{array}$ & $\begin{array}{l}50 \text { patients were randomized to } \\
100 \mathrm{mg} \text { daily, } 200 \mathrm{mg} \text { daily, } 200 \mathrm{mg} \\
\text { twice daily, } 600 \mathrm{mg} \text { daily, or } \\
\text { placebo for } 28 \text { days }\end{array}$ & $\begin{array}{l}\text { Mean PGA } \\
\text { reduction } \\
\text { from } \\
\text { baseline }\end{array}$ & $\begin{array}{l}\text { A significant improvement in mean } \\
\text { percent reduction in PGA from } \\
\text { baseline was observed for the } \\
200 \mathrm{mg} \text { twice daily and } 600 \mathrm{mg} \\
\text { daily groups compared to placebo } \\
\text { Mean PGA reduction from baseline: } \\
22.2 \% \text { (100 mg daily), } 29.4 \% \\
\text { (200 mg daily), } 35.2 \% \text { ( } 200 \mathrm{mg} \\
\text { twice daily), 42.4\% (600 mg daily), } \\
12.5 \% \text { (placebo) }\end{array}$ \\
\hline
\end{tabular}




\section{DISCUSSION}

The number of studies on JAK inhibitors for psoriasis remains limited. Many of the drugs tested have only been examined in phase 2 trials and it is doubtful that they will be tested further. Only tofacitinib has been tested to phase 3 , and several phase 3 trials are currently in progress for the TYK2 inhibitor BMS-986165. The selective TYK2 inhibitor BMS-986165 has shown the highest efficacy towards psoriasis of any JAK inhibitor to date, with a PASI75 response of $75 \%$ after 12 weeks of treatment in a phase 2 trial [17]. Tofacitinib is the most studied JAK inhibitor for the treatment of psoriasis, with four reported phase 3 trials showing considerable efficacy in terms of the PASI75 response, especially at a high dose of $10 \mathrm{mg}$ twice daily [13-16]. Other JAK inhibitors have also been tested for psoriasis; these have yielded PASI75 responses that are less than or similar to that achieved with tofacitinib. However, none of these have been tested beyond phase 2 [18-21].

There is fierce competition in the pharmaceutical industry due to the number of biological drugs on the market that are all very effective at treating psoriasis and have relatively few side effects. The standard efficacy target for new biological treatments for psoriasis is PASI90, as seen in up to $60-70 \%$ of patients $[3,22]$. For the highest dose of BMS-986165 tested, PASI90 was 43\% [16]. Accordingly, current data do not indicate that new JAK inhibitors, including TYK2 inhibitors, will outperform the newest biologics. However, the efficacies observed for JAK inhibitors are better than those observed for some current systemic treatments such as apremilast, and some of the older biologics such as etanercept [3]. Provided that they do not present increased adverse reaction rates, JAK inhibitors could be incorporated into the psoriasis treatment algorithm because they are oral treatments and are less expensive than contemporary biologics.

Knowledge of the safety of JAK inhibitors is predominantly based on studies of tofacitinib, especially when administered for RA. Tofacitinib has been associated with changes in laboratory parameters in patients with RA and psoriasis, and increases in HDL and LDL cholesterol levels have been observed in both patient groups [23, 24]. Patients with psoriasis are known to have an increased risk of cardiovascular disease-especially patients with moderate-to-severe disease $[25,26]$. In a study investigating the effects of tofacitinib on lipid levels in such patients, increases from baseline levels of LDL cholesterol, HDL cholesterol, and triglycerides were observed at week 4 compared to placebo, but these levels were relatively stable from weeks 4 to 16 . The total cholesterol to HDL cholesterol ratio did not change and the investigators therefore concluded that the observed changes in lipid levels were not suggestive of an increased cardiovascular risk [23]. Also, an investigation of circulating levels of proteins associated with inflammation and cardiovascular risk in patients with moderate-tosevere psoriasis treated with tofacitinib for 12 weeks showed that this drug reduced several inflammatory cardiovascular risk markers. However, it only did so in treatment responders [26]. The conclusion was that short-term systemic treatment of psoriasis with tofacitinib can cause reductions in circulating levels of inflammatory proteins and other proteins associated with cardiovascular risk [27]. Notably, increased serum creatinine levels are associated with tofacitinib, but these levels usually return to baseline upon drug discontinuation, and chronic renal dysfunction is not reported to be an adverse effect of tofacitinib [6, 28].

These studies indicate that treatment with tofacitinib probably does not increase cardiovascular risk in patients with psoriasis, but the results are based on short-term use, so further studies are needed to explore the effects of longterm use in particular.

An increased risk of infection should always be considered when a treatment targeting the immune system is used. Minor decreases in blood lymphocyte counts and hemoglobin have been observed in patients with psoriasis treated with tofacitinib. These decreases were not progressive and were often transient or reversible [29]. Tofacitinib has been associated with an increased risk of herpes zoster virus infection compared to placebo. Risk factors included 
Asian race, increasing age, higher drug dose, and prior exposure to biologics [30]. Also, an investigation of the effects of tofacitinib on the viral loads of Cytomegalovirus and Epstein-Barr virus pointed to no clinically significant effects of this JAK inhibitor [31]. The risk of infection during treatment with tofacitinib seems to be similar to that during treatment with biologics $[6,9]$, and the overall benefit/risk profile of the drug when used for psoriasis appears to be comparable to those of other systemic treatments [32].

Both the US Food and Drug Administration and the European Medicines Agency recently issued black-box warnings of increased risks of pulmonary embolism and overall mortality in patients with RA receiving tofacitinib $10 \mathrm{mg}$ twice daily. These warnings were given due to the results of an interim analysis of an ongoing open-label clinical trial evaluating the safety of tofacitinib $5 \mathrm{mg}$ twice or $10 \mathrm{mg}$ twice daily compared with a TNF inhibitor in patients with RA (NCT A3921133) [33, 34]. An independent study also indicated a numerically higher, albeit statistically insignificant, risk of venous thromboembolism in RA patients receiving tofacitinib compared to those receiving TNF inhibitors [35].

We do not yet know the complete safety profiles and side effects of TYK2 inhibitors when they are used for psoriasis, but judging from the results of the only published phase 2 study of BMS-986165, where no changes in laboratory parameters were observed, this agent may have a better risk profile than tofacitinib [17]. It will be exciting to see the results of the phase 3 studies of this agent that are currently in progress, and these data will provide a much better basis for comparison with currently marketed biologics.

Tofacitinib is approved for psoriatic arthritis by both the US Food and Drug Administration and the European Medicines Agency. It is indicated for patients that have an inadequate response to conventional treatment with disease-modifying antirheumatic drugs (DMARDs), and it is further recommended for use in combination with a DMARD such as methotrexate, sulfasalazine, and leflunomide [36]. In clinical trials, the efficacy of tofacitinib has been measured in terms of the American College of Rheumatology 20 (ACR20) response and the change from baseline in the Health Assessment Questionnaire-Disability Index (HAQ-DI) score. In one study testing tofacitinib in patients with active psoriatic arthritis that had responded inadequately to DMARDs, the ACR20 was $50 \%$ (5 mg twice daily) and $61 \%$ (10 mg twice daily) compared to $33 \%$ for placebo after 3 months. The mean change in the HAQ-DI score was - 0.35 (5 mg twice daily) and - 0.40 (10 mg twice daily) compared with 0.18 for placebo [37]. Another study tested tofacitinib in patients with active psoriatic arthritis that had responded inadequately to TNF inhibitors. The ACR20 response after 3 months was 50\% (5 mg twice daily) and 47\% (10 mg twice daily) compared with $24 \%$ for placebo; the corresponding mean changes in the HAQ-DI score from baseline were -0.39 and -0.35 , compared with -0.14 for placebo [38].

Although not covered in this review, one particularly exciting area of research is the use of JAK inhibitors as a local treatment for psoriasis, since new topical treatments for mild psoriasis are urgently needed. Topical formulations of tofacitinib and ruxolitinib have been tested in a few phase 2 trials for psoriasis. Topical tofacitinib showed significant efficacy at 8 weeks of treatment compared to placebo, but the effect was transient and was not apparent at 12 weeks, when the study ended [39]. Ruxolitinib showed clinical efficacy towards psoriasis after 4 weeks of treatment, and was shown to modulate proinflammatory cytokines in psoriatic lesions [40]. Importantly, no local or systemic adverse effects were observed with topical treatment, and more studies on this interesting field of research are awaited.

\section{CONCLUSIONS}

JAK inhibitors are an exciting new group of drugs for the treatment of psoriasis. Tofacitinib is the best-studied JAK inhibitor for psoriasis to date; it has demonstrated considerable clinical efficacy and is well tolerated overall when used for a short period. Selective TYK2 inhibitors 
have shown even better clinical efficacy in psoriasis, and seem to have an improved safety profile, but only the results from one phase 2 trial of a selective TYK2 inhibitor have been published. It is therefore clear that more studies are needed to determine the long-term effects and safety of JAK inhibitors.

\section{ACKNOWLEDGEMENTS}

Funding. No funding or sponsorship was received for this study or the publication of this article.

Authorship. All named authors meet the International Committee of Medical Journal Editors (ICMJE) criteria for authorship for this article, take responsibility for the integrity of the work as a whole, and have given their approval for this version to be published.

Disclosures. Amanda Kvist-Hansen has nothing to disclose. Peter Riis Hansen is supported by a Borregaard Clinical Scientist fellowship from the Novo Nordisk Foundation and research grants from the LEO Foundation. Lone Skov has received speaker honoraria from AbbVie, Eli Lilly \& Co, Novartis, and LEO Pharma, and has attended advisory boards for AbbVie, Janssen-Cilag, Novartis, Eli Lilly \& Co, UCB, Almirall, LEO Pharma, and Sanofi. She has served as an investigator for Pfizer, AbbVie, Eli Lilly, Novartis, Amgen, Regeneron, Almirall, and LEO Pharma, and received research and educational grants from Pfizer, AbbVie, Novartis, Sanofi, Janssen-Cilag, and LEO Pharma.

Compliance with Ethics Guidelines. This article is based on previously conducted studies and does not contain any studies with human participants or animals performed by any of the authors.

Data Availability. Data sharing is not applicable to this article as no datasets were generated or analyzed during the current study.
Open Access. This article is licensed under a Creative Commons Attribution-NonCommercial 4.0 International License, which permits any non-commercial use, sharing, adaptation, distribution and reproduction in any medium or format, as long as you give appropriate credit to the original author(s) and the source, provide a link to the Creative Commons licence, and indicate if changes were made. The images or other third party material in this article are included in the article's Creative Commons licence, unless indicated otherwise in a credit line to the material. If material is not included in the article's Creative Commons licence and your intended use is not permitted by statutory regulation or exceeds the permitted use, you will need to obtain permission directly from the copyright holder. To view a copy of this licence, visit http://creativecommons.org/licenses/by$\mathrm{nc} / 4.0 /$.

\section{REFERENCES}

1. Nestle FO, Kaplan DH, Barker J. Psoriasis. N Engl J Med. 2009;361:496-509.

2. Boehncke W-H, Schön MP. Psoriasis. Lancet. 2015;386:983-94.

3. Sawyer LM, Malottki K, Sabry-Grant C, et al. Assessing the relative efficacy of interleukin-17 and interleukin-23 targeted treatments for moderate-tosevere plaque psoriasis: a systematic review and network meta-analysis of PASI response. PLoS One. 2019;14:e0220868.

4. Egeberg A, Ottosen MB, Gniadecki R, et al. Safety, efficacy and drug survival of biologics and biosimilars for moderate-to-severe plaque psoriasis. $\mathrm{Br} \mathrm{J}$ Dermatol. 2018;178:509-19.

5. Warren RB, Smith CH, Yiu ZZN, et al. Differential drug survival of biologic therapies for the treatment of psoriasis: a prospective observational cohort study from the British Association of Dermatologists Biologic Interventions Register (BADBIR). J Invest Dermatol. 2015;135:2632-40.

6. Schwartz DM, Kanno Y, Villarino A, Ward M, Gadina M, O'Shea JJ. JAK inhibition as a therapeutic strategy for immune and inflammatory diseases. Nat Rev Drug Discov. 2017;17:78. 
7. He X, Chen X, Zhang H, Xie T, Ye XY. Selective Tyk2 inhibitors as potential therapeutic agents: a patent review (2015-2018). Expert Opin Ther Pat. 2019;20:137-49.

8. Hsu L, Armstrong AW. JAK inhibitors: treatment efficacy and safety profile in patients with psoriasis. J Immunol Res. 2014;2014:283617.

9. Szilveszter KP, Németh T, Mócsai A. Tyrosine kinases in autoimmune and inflammatory skin diseases. Front Immunol. 2019;10:1862.

10. Singh S, Pradhan D, Puri P, et al. Genomic alterations driving psoriasis pathogenesis. Gene. 2019;683:61-71.

11. Ishizaki M, Muromoto R, Akimoto T, et al. Tyk2 is a therapeutic target for psoriasis-like skin inflammation. Int Immunol. 2014;26:257-67.

12. Papp KA, Menter A, Strober B, et al. Efficacy and safety of tofacitinib, an oral Janus kinase inhibitor, in the treatment of psoriasis: a phase $2 \mathrm{~b}$ randomized placebo-controlled dose-ranging study. $\mathrm{Br} \mathrm{J}$ Dermatol. 2012;167:668-77.

13. Papp KA, Menter MA, Abe M, et al. Tofacitinib, an oral Janus kinase inhibitor, for the treatment of chronic plaque psoriasis: results from two randomized, placebo-controlled, phase III trials. $\mathrm{Br} \mathrm{J}$ Dermatol. 2015;173:949-61.

14. Bissonnette $\mathrm{R}$, Iversen $\mathrm{L}$, Sofen $\mathrm{H}$, et al. Tofacitinib withdrawal and retreatment in moderate-to-severe chronic plaque psoriasis: a randomized controlled trial. Br J Dermatol. 2015;172:1395-406.

15. Bachelez $H$, van de Kerkhof PCM, Strohal R, et al. Tofacitinib versus etanercept or placebo in moderate-to-severe chronic plaque psoriasis: a phase 3 randomised non-inferiority trial. Lancet (London, England). 2015;386:552-61.

16. Zhang J, Tsai T-F, Lee M-G, et al. The efficacy and safety of tofacitinib in Asian patients with moderate to severe chronic plaque psoriasis: a phase 3 , randomized, double-blind, placebo-controlled study. J Dermatol Sci. 2017;88:36-45.

17. Papp K, Gordon K, Thaçi D, et al. Phase 2 trial of selective tyrosine kinase 2 inhibition in psoriasis. N Engl J Med. 2018;379:1313-21.

18. Ludbrook VJ, Hicks KJ, Hanrott KE, et al. Investigation of selective JAK1 inhibitor GSK2586184 for the treatment of psoriasis in a randomized placebocontrolled phase IIa study. Br J Dermatol. 2016;174: 985-95.

19. Bissonnette R, Luchi M, Fidelus-Gort R, et al. A randomized, double-blind, placebo-controlled, dose-escalation study of the safety and efficacy of INCB039110, an oral Janus kinase 1 inhibitor, in patients with stable, chronic plaque psoriasis. J Dermatolog Treat. 2016;27:332-8.

20. Papp K, Pariser D, Catlin M, et al. A phase 2a randomized, double-blind, placebo-controlled, sequential dose-escalation study to evaluate the efficacy and safety of ASP015K, a novel Janus kinase inhibitor, in patients with moderate-to-severe psoriasis. Br J Dermatol. 2015;173:767-76.

21. Papp KA, Menter MA, Raman M, et al. A randomized phase $2 \mathrm{~b}$ trial of baricitinib, an oral Janus kinase (JAK) 1/JAK2 inhibitor, in patients with moderate-to-severe psoriasis. $\mathrm{Br} \mathrm{J}$ Dermatol. 2016;174:1266-76.

22. Puig L. PASI90 response: the new standard in therapeutic efficacy for psoriasis. J Eur Acad Dermatol Venereol. 2015;10:645-8.

23. Wolk R, Armstrong EJ, Hansen PR, et al. Effect of tofacitinib on lipid levels and lipid-related parameters in patients with moderate to severe psoriasis. J Clin Lipidol. 2017;11:1243-56.

24. Charles-Schoeman C, Wicker P, Gonzalez-Gay MA, et al. Cardiovascular safety findings in patients with rheumatoid arthritis treated with tofacitinib, an oral Janus kinase inhibitor. Semin Arthritis Rheum. 2016;46:261-71.

25. Ahlehoff O, Gislason GH, Charlot M, et al. Psoriasis is associated with clinically significant cardiovascular risk: a Danish nationwide cohort study. J Intern Med. 2011;270:147-57.

26. Samarasekera EJ, Neilson JM, Warren RB, Parnham $\mathrm{J}$, Smith $\mathrm{CH}$. Incidence of cardiovascular disease in individuals with psoriasis: a systematic review and meta-analysis. J Invest Dermatol. 2013;133:2340-6.

27. Kim J, Tomalin L, Lee J, et al. Reduction of inflammatory and cardiovascular proteins in the blood of patients with psoriasis: differential responses between tofacitinib and etanercept after 4 weeks of treatment. J Invest Dermatol. 2018;138: 273-81.

28. Kremer JM, Kivitz AJ, Simon-Campos JA, et al. Evaluation of the effect of tofacitinib on measured glomerular filtration rate in patients with active rheumatoid arthritis: results from a randomised controlled trial. Arthritis Res Ther. 2015;17:95.

29. Strober B, Buonanno M, Clark JD, et al. Effect of tofacitinib, a Janus kinase inhibitor, on haematological parameters during 12 weeks of psoriasis treatment. Br J Dermatol. 2013;169:992-9. 
30. Winthrop KL, Lebwohl M, Cohen AD, et al. Herpes zoster in psoriasis patients treated with tofacitinib. J Am Acad Dermatol. 2017;77:302-9.

31. Valenzuela F, Papp KA, Pariser D, et al. Effects of tofacitinib on lymphocyte sub-populations, CMV and EBV viral load in patients with plaque psoriasis. BMC Dermatol. 2015;20:15.

32. Strober BE, Gottlieb AB, van de Kerkhof PCM, et al. Benefit-risk profile of tofacitinib in patients with moderate-to-severe chronic plaque psoriasis: pooled analysis across six clinical trials. $\mathrm{Br} \mathrm{J}$ Dermatol. 2019;180:67-75.

33. US Food and Drug Administration. Safety trial finds risk of blood clots in the lungs and death with higher dose of tofacitinib (Xeljanz, Xeljanz XR) in rheumatoid arthritis patients; FDA to investigate [Internet]. Silver Spring: US FDA; 2019. Available at: https://www.fda.gov/drugs/drug-safetyand-availability/safety-trial-finds-risk-blood-clotslungs-and-death-higher-dose-tofacitinib-xeljanzxeljanz-xr. Accessed November 2019.

34. European Medicines Agency. Restrictions in use of Xeljanz while EMA reviews risk of blood clots in lungs. London: EMA; 2019. Available at: https://www. ema.europa.eu/en/news/restrictions-use-xeljanzwhile-ema-reviews-risk-blood-clots-lungs. Accessed November 2019.

35. Desai RJ, Pawar A, Weinblatt ME, Kim SC. Comparative risk of venous thromboembolism in rheumatoid arthritis patients receiving tofacitinib versus those receiving tumor necrosis factor inhibitors: an observational cohort study. Arthritis Rheumatol. 2019;71:892-900.

36. Ly K, Beck KM, Smith MP, Orbai A-M, Liao W. Tofacitinib in the management of active psoriatic arthritis: patient selection and perspectives. Psoriasis (Auckland, NZ). 2019;9:97-107.

37. Mease P, Hall S, FitzGerald $\mathrm{O}$, et al. Tofacitinib or adalimumab versus placebo for psoriatic arthritis. N Engl J Med. 2017;377:1537-50.
38. Gladman D, Rigby W, Azevedo VF, et al. Tofacitinib for psoriatic arthritis in patients with an inadequate response to TNF inhibitors. N Engl J Med. 2017;377: 1525-36.

39. Papp KA, Bissonnette R, Gooderham $\mathrm{M}$, et al. Treatment of plaque psoriasis with an ointment formulation of the Janus kinase inhibitor, tofacitinib: a phase $2 \mathrm{~b}$ randomized clinical trial. BMC Dermatol. 2016;16:15.

40. Punwani N, Burn T, Scherle P, et al. Downmodulation of key inflammatory cell markers with a topical Janus kinase 1/2 inhibitor. Br J Dermatol. 2015;173: 989-97.

41. US National Library of Medicine. ClinicalTrials.gov database [Internet]. Bethesda: US National Library of Medicine; 2019. Available at: https://clinical trials.gov/ct2/results?cond=\&term=NCT04036435\& cntry $=\&$ state $=\&$ city $=\&$ dist $=$. Accessed August 2019.

42. US National Library of Medicine. ClinicalTrials.gov database [Internet]. Bethesda: US National Library of Medicine; 2019. Available at: https://clinical trials.gov/ct2/results?cond=\&term $=$ NCT03924427\& cntry $=\&$ state $=\&$ city $=\&$ dist $=$. Accessed August 2019 .

43. US National Library of Medicine. ClinicalTrials.gov database [Internet]. Bethesda: US National Library of Medicine; 2019. Available at: https://clinical trials.gov/ct2/results?cond=\&term $=$ NCT03611751\& cntry $=\&$ state $=\&$ city $=\&$ dist $=$. Accessed August 2019.

44. US National Library of Medicine. ClinicalTrials.gov database [Internet]. Bethesda: US National Library of Medicine; 2019. Available at: https://clinical trials.gov/ct2/results?cond=\&term=NCT03624127\& cntry $=\&$ state $=\&$ city $=\&$ dist $=$. Accessed August 2019.

45. US National Library of Medicine. ClinicalTrials.gov database [Internet]. Bethesda: US National Library of Medicine; 2019. Available at: https://clinical trials.gov/ct2/results?cond=\&term=NCT03895372\& cntry $=\&$ state $=\&$ city $=\&$ dist $=$. Accessed August 2019. 